\title{
JURNAL PLANS
}

Penelitian Ilmu Manajemen \& Bisnis

\section{PENGARUH ATRIBUT PRODUK PESTISIDA ANTRACOL 70 WP TERHADAP KEPUASAN PETANI PADI PADA PT. BAYER CROPSCIENCE}

(Studi Kasus: Desa Bah Jambi II Kecamatan Tanah Jawa Kabupaten Simalungun)

\author{
Hendra Saputra \\ Dosen Jurusan Manajemen Fakultas Ekonomi Universitas Negeri Medan \\ Christin Natalia Sianipar \\ Alumni Jurusan Manajemen Fakultas Ekonomi Universitas Negeri Medan
}

\begin{abstract}
Abstrak
Penelitian ini bertujuan untuk mengetahui pengaruh harga, desain produk, dan kualitas produk terhadap kepuasan konsumen petani padi pada produk pestisida Antracol PT Bayer CropScience. Penelitian ini dilaksanakan dengan menggunakan metode total sampling yang berjumlah 50 orang petani Teknik pengumpulan data diperoleh dengan cara observasi, dan angket (kuesioner) yang pengukurannya menggunakan skala Likert. Dan diolah secara statistik dengan metode Analisis Regresi Berganda dengan persamaan struktural $Y=a+b_{1} X_{1}+b_{2} X_{2}+b_{3} X_{3}$ serta diolah dengan menggunakan SPSS17.00 for windows. Dari hasil data maka diperoleh persamaan analisis regresi berganda $Y$ $=3,352+0,359 X_{1}+0,184 X_{2}+0,519 X_{3}$. Kontribusi variabel bebas terhadap variabel terikat diketahui dengan koefisien determinan $\left(R_{\text {square }}\right)$ dengan hasil sebesar 75,5\% dan sisanya sebesar 24,5\% dijelaskan oleh variabel lain. Harga, desain produk dan kualitas produk berpengaruh secara simultan terhadap kepuasan konsumen produk antracol 70 WP kepada petani Desa Bah Jambi II Kecamatan Tanah Jawa Kabupaten Simalungun. Hal ini terlihat dari $F_{\text {hitung }}>$ $F_{\text {tabel }}$ yaitu 47,318 $>2,79$ pada $a=5 \%$. Secara parsial harga berpengaruh terhadap kepuasan konsumen dengan nilai $t_{\text {hitung }}>t_{\text {tabel }}$ yaitu 5,424 $>2,001$, desain produk berpengaruh terhadap kepusan konsumen dengan nilai $t_{\text {hitung }}>t_{\text {tabel }}$ yaitu 2,674 > 2,001, dan kualitas produk berpengatuh terhadap kepuasan konsumen $t_{\text {hitung }}>t_{\text {tabel }}$ yaitu 6,426 > 2,001. Dengan demikian hipotesis dalam penelitian ini dapat diterima yaitu ada pengaruh harga, desain produk dan kualitas produk terhadap kepuasan konsumen pada produk antracol $70 \mathrm{WP}$ di kalangan petani padi Desa Bah Jambi II.
\end{abstract}

Kata kunci: Harga, Desain Produk, Kualitas Produk, Kepuasan Konsumen.

\section{PENDAHULUAN}

Indonesia merupakan salah satu negara berkembang dengan sektor pertanian sebagai sumber mata pencaharian dari mayoritas penduduknya. Artinya sebagian besar penduduknya menggantungkan hidupnya pada sektor pertanian. Dengan begitu, Sektor pertanian memiliki peranan yang sangat penting dalam perkembangan perekonomian nasional Indonesia. Indonesia sebagai negara agraris menitikberatkan pembangunannya pada sektor pertanian. Pembanguan pada sektor pertanian bertujuan untuk menaikkan produksi pertanian, pemerataan pendapatan dan sekaligus 
Penelitian Ilmu Manajemen \& Bisnis

mempertahankan kelestarian sumber daya alam dan lingkungan. Dengan adanya pertumbuhan sektor pertanian akan berimbas pada naiknya input sehingga mengakibatkan pemakaian pestisida yang semakin meningkat.

Pestisida merupakan zat kimia, bahan lain jasad renik dan virus yang dipergunakan untuk mengendalikan OPT (Organisme Penganggu Tanaman) serta mengatur atau merangsang pertumbuhan tanaman atau bagian-bagian tanaman. Pada umumnya pestida hanya efektif terhadap spesies organisme penganggu tertentu, oleh karena itu untuk pengendalian berbagai jenis organisme penganggu tersebut yang masing-masing terdiri dari banyak spesies, diperlukan berbagai jenis dan formulasi pestisida.

Padi merupakan tanaman yang memberikan peranan yang sangat penting bagi perekonomian secara nasional.. Peningkatan produksi padi tentu mengalami masalah-masalah yang dihadapi cukup serius, yaitu serangan hama dan penyakit tanaman atau sering disebut organisme penganggu tanaman (OPT). Tanaman padi itu lebih rentan terkena hama dan penyakit dibandingkan dengan jagung, kedelai, kopi, dan lain-lain.

Kabupaten Simalungun memilki 33 kecamatan dengan luas lahan padi sekitar 39.721 Ha. Nagori Bahjambi II adalah salah satu desa di Kabupaten Simalungun yang merupakan desa penghasil padi dan juga sebagai penghasil beras terbesar di kecamatan Tanah Jawa. Untuk meningkatkan produktivitas pada Desa Bah Jambi II tentunya membutuhkan pestisida sebagai pembasmi hama pertanian.

Semakin meningkatnya kebutuhan petani akan produk pestisida yang dapat membantu mereka membasmi hama, menjadikan
Vol. 10 No. 1 Maret 2015

semakin banyaknya bermunculan perusahaan yang menjual produk sejenis. Dengan begitu, akan terjadi peningkatan persaingan dalam bidang bisnis ini juga. Setiap perusahaan yang bergerak didalamnya harus memiliki strategi yang efektif dan efisien untuk tetap bertahan dan meningkatkan persaingan. Mempertahankan kepuasan pelanggan merupakan salah satu langkah yang dapat diterapkan oleh perusahaan untuk dapat bersaing dan menguasai pangsa pasar.

PT Bayer CropScience merupakan perusahaan yang menghasilkan produk pestisida Antracol. Namun, perusahaan ini bukan satu-satunya perusahaan agrokimia yang masuk ke desa Bah Jambi II untuk memasarkan produk Antracol $70 \mathrm{WP}$, tetapi masih ada beberapa perusahaan agrokimia seperti: Syngenta Agri Products Indonesia, Dow Agro Science, Du Pont Indonesia, $\mathrm{FMC}, \mathrm{Nu}$ Farm, Monargo Kimia, BASF, Agricon, Petrokimia dan perusahaan nasional yang menghasilkan produk generik.

Pihak perusahaan harus memperhatikan nilai produk yang sudah tertanam di hati konsumen atau lebih mengembangkannya guna mempertahankan nilai produk itu sendiri bagi konsumen. Atribut produk merupakan unsur-unsur yang dianggap penting oleh konsumen dan dijadikan dasar pengambilan keputusan untuk membeli suatu produk. Menurut Peter dan Olson (dalam Hidayani, 2013:3) atribut produk terdiri dari, harga, desain, warna, kualitas, fitur, dan merk produk. Semua atribut produk ini menjadi bahan pertimbangan penting dalam meluncurkan suatu produk, karena produk diluncurkan sangat ditentukan oleh atribut-atribut produk 


\section{JURNAL PLANS}

yang mampu memberikan kepuasan kepada konsumen.

Setelah peneliti amati dan melakukan wawancara kepada para petani, mereka mengatakan produk pestisida Antracol dari PT. Bayer CropScience lebih bagus dari pada produk generik. Menurut para petani, kualitas produk pestisida Antracol 70 WP lebih baik dibandingkan dengan produk generic dan desain kemasannya menarik, karena produk antracol lebih cepat memberikan dampak yang baik terhadap padi . Namun, meskipun pestisida Antracol memberikan hasil yang bermanfaat bagi para petani, namun terdapat kendala dari segi harga pada pestisida Antracol 70 WP ini. Harga produk Antracol jauh lebih mahal dibandingkan produk generik.

Adanya kendala yang terdapat pada produk Antracol 70 WP ini menjadikan peneliti ingin mengetahui pengaruh atribut produk terhadap kepuasan konsumen yang menggunakan produk Antracol 70 WP dari PT. Bayer CorpScience. Dengan begitu, maka perusahaan dapat mengetahui seberapa besar tingkat kepuasan konsumen yang telah menggunakan produk pestisida mereka.

Produk memiliki ciri-ciri yaitu berwujud, memiliki nilai dan manfaatnya dapat dirasakan saat digunakan. Produk yang dipasarkan termasuk produk fisik, jasa, tempat dan ide. Kemudian Simamora (2007:400) mendefenisikan "Produk merupakan segala sesuatu yang diterima oleh konsumen atau pembeli/pemakai industrial pada saat melakukan pembelian atau penggunaan produk".

Harga merupakan satusatunya unsur bauran pemasaran yang menghasilkan pendapatan bagi
Penelitian Ilmu Manajemen \& Bisnis

Vol. 10 No. 1 Maret 2015

perusahaan sehingga perusahaan harus mampu menetapkan harga produknya dengan baik dan tepat sehingga konsumen tertarik dan mau membeli produk yang ditawarkan oleh perusahaan tersebut. Menurut Kotler (2002 : 195) harga adalah : "Nilai yang dipertukarkan konsumen untuk suatu manfaat atas pengkonsumsian, penggunaan tau kepemilikan barang dan jasa".

Menurut Kotler (2001:353) defenisi desain adalah "Totalitas fitur yang memperuhi penampilan dan fungsi produk tertentu menurut yang diisyaratkan oleh pelanggan". Berbicara mengenai produk maka askpek yang perlu diperhatikan adalah kualitas produk. Kualitas produk telah menjadi faktor penentu kesuksesan atau kegagalan bisnis utama yang dewasa ini. American Society Quality Control), (dalam Tjiptono, 2001:51) mendefenisikan "Kualitas adalah keseluruhan ciri dan karakter-karakter dari sebuah produk atau jasa yang menunjukkan kemampuannya untuk memuaskan kebutuhan yang tersirat".

Kata kepuasan (statisfaction) berasal dari bahasa latin "statis" (artinya cukup baik, memadai) dan "facio" (melakukan atau membuat). Kepuasan bisa diartikan sebagai usaha pemenuhan sesuatu atau membuat sesuatu memadai. Menurut Kotler (2007:177) "Kepuasan adalah perasaan senang atau kecewa seseorang yang muncul setelah membandingkan persepsi /kesannya terhadap kinerja (atau hasil) suatu produk dan harapan-harapannya”.

\section{METODE PENELITIAN \\ Lokasi dan Waktu Penelitian}

Penelitian ini dilaksanakan di Nagori Bahjambi II Kecamatan Tanah Jawa Kabupaten Simalungun. 


\section{JURNAL PLANS}

Populasi dan Sampel

Berdasarkan hasil wawancara dengan petugas PT.Bayer CropScience yang menjadi populasi dalam penelitian ini adalah para petani yang pernah menggunakan produk pestisida Antracol $70 \mathrm{WP}$ di Nagori Bah Jambi II Kecamatan Tanah Jawa Kabupaten Simalungun yaitu 50 petani. Yang menjadi sampel dalam penelitian ini seluruh populasi yaitu 50 petani.

\section{Variabel Penelitian dan Defenisi Operasional \\ Variabel Penelitian}

Variabel penelitian terdiri dari variabel bebas dan variabel terikat. Variabel bebas (X) merupakan gejala atau faktor atau unsur yang menentukan atau mempengaruhi variabel terikat.

Variabel Bebas

Variabel bebas yaitu variabel yang menjadi sebab terjadinya atau terpengaruhnya variabel terikat. Tujuannya untuk mengetahui ada tidaknya hubungan antara dua set variabel (Ghozali, 2006:45). Dalam penelitian ini yang menjadi variabel bebas adalah : Harga $\left(\mathrm{X}_{1}\right)$, Desain Produk $\left(\mathrm{X}_{2}\right)$ dan Kualitas Produk $\left(\mathrm{X}_{3}\right)$ Variabel Terikat

Variabel terikat adalah variabel yang nilainya dipengaruhi oleh variabel bebas. Tujuannya adalah untuk menentukan apakah variabel bebas dipengaruhi variabel terikat secara individual dan atau bersamaan (Ghozali, 2006:45). Dalam penelitian ini yang menjadi variabel terikat adalah : Kepuasan Konsumen (Y)

\section{Defenisi Operasional}

Harga $\left(\mathrm{X}_{1}\right)$ adalah sejumlah uang yang dibebankan atas suatu produk, atau jumlah dari nilai yang ditukar oleh konsumen atas manfaatmanfaat karena memiliki atau
Penelitian Ilmu Manajemen \& Bisnis

Vol. 10 No. 1 Maret 2015 menggunakan produk tersebut. Indikator harga yaitu :

1. Keterjangkauan harga

2. Harga sesuai dengan kualitas produk

3. Potongan harga (diskon)

Desain Produk $\left(\mathrm{X}_{2}\right)$ adalah Totalitas fitur yang memperuhi penampilan dan fungsi produk tertentu menurut yang diisyaratkan oleh pelanggan. Indikator desain produk yaitu:

1. Gaya

2. Daya Tahan

3. Keandalan

Kualitas Produk $\left(\mathrm{X}_{3}\right)$ adalah kualitas produk merupakan pemahaman bahwa produk yang ditawarkan oleh suatu perusahaan mempunyai nilai jual lebih yang tidak dimiliki oleh produk pesaing.. indikator kualitas harga yaitu:

1. Bentuk

2. Kinerja

3. Keandalan

4. Pelayanan

Kepuasan konsumen

adalah perasaan senang atau kecewa seseorang yang muncul setelah membandingkan persepsi /kesannya terhadap kinerja (atau hasil) suatu produk dan harapan-harapannya. Indikator kepuasan konsumen, yaitu:

1. Kualitas produk

2. Kualitas pelayanan

3. Harga

4. Biaya dan kemudahan

\section{Teknik Analisis Data}

Teknik analisis data adalah cara yang digunakan untuk memudahkan atau menyederhanakan pengelolahan data dalam bentuk yang lebih mudah dibaca dan dimenegerti. Untuk menegetahui pengaruh harga ( $\left.\mathrm{X}_{1}\right)$, desain produk $\left(\mathrm{X}_{2}\right)$ dan kualitas produk $\left(\mathrm{X}_{3}\right)$ dengan kepuasan konsumen $(\mathrm{Y})$. Teknik analisis data 


\section{JURNAL PLANS}

Penelitian Ilmu Manajemen \& Bisnis

yang dipergunakan dalam penelitian ini adalah Analisis Regresi Berganda.

Metode Analisis Regresi Berganda

Analisis regresi berganda digunakan untuk mengetahui pengaruh antara variabel bebas dengan variabel terikat yaitu antara harga $\left(\mathrm{X}_{1}\right)$, desain produk $\left(\mathrm{X}_{2}\right)$ dan kualitas $\left(\mathrm{X}_{2}\right)$ terhadap kepuasan konsumen (Y). Selain itu, analisis regresi berganda juga digunakan untuk mengetahui sejauh mana besarnya pengaruh antara variabel bebas dan variabel terikat, maka peneliti menggunakan Teknik Analisis Regresi Berganda (Sugiyono,2008:277) :

$$
\mathbf{Y}=\mathbf{a}+\boldsymbol{\beta}_{1} \mathbf{X}_{1}+\boldsymbol{\beta}_{2} \mathbf{X}_{2}+\beta_{3} \mathbf{X}_{3}+
$$

Dimana :

$$
\begin{array}{ll}
\mathrm{Y} & =\text { Kepuasan konsumen } \\
\mathrm{a} & =\text { Konstanta } \\
\mathrm{X}_{1} & =\text { Harga } \\
\mathrm{X}_{2} & =\text { Desain Produk } \\
\mathrm{X}_{3} & =\text { Kualitas produk } \\
\beta_{1} & =\text { Koefisien regresi } \mathrm{X}_{1} \\
\beta_{2} & =\text { Koefisien regresi } \mathrm{X}_{2} \\
\beta_{3} & =\text { Koefisien regresi } \mathrm{X}_{3} \\
\mathrm{e} & =\text { error }
\end{array}
$$

\section{Uji Hipotesis}

Untuk mengetahui signifikasi dari hipotesa dalam penelitian ini, maka perlu dilakukan beberapa uji sebagai berikut :

\section{Uji t (Parsial)}

Uji t dilakukan untuk menguji hipotesis yang telah dirumuskan yaitu mengetahui apakah variabel harga $\left(\mathrm{X}_{1}\right)$, desain produk $\left(\mathrm{X}_{2}\right)$ dan kualitas produk $\left(\mathrm{X}_{3}\right)$ berpengaruh positif dan signifikan terhadap variabel kepuasan konsumen (Y). Untuk itu, maka peneliti menggunakan rumus sebagai berikut (Purwanto,2004:56) :
Vol. 10 No. 1 Maret 2015

$$
\boldsymbol{t}=\frac{\boldsymbol{b}-\boldsymbol{\beta}}{\boldsymbol{s b}}
$$

Jika $t_{\text {hitung }} \geq t_{\text {tabel }}$, pada taraf kepercayaan $95 \%$ atau $=5 \%$, maka hipotesis dalam penelitian ini diterima.

Jika $t_{\text {hitung }} \leq t_{\text {tabol }}$, pada taraf kepercayaan $95 \%$ atau $=5 \%$, maka hipotesis dalam penelitian ini ditolak.

\section{Uji Signifikasi Simultan (Uji F)}

Pengujian ini dilakukan untuk mengetahui apakah semua variabel independen secara bersama-sama (simultan) dapat berpengaruh terhadap variabel 32dependen. Uji F merupakan pengujian signifikan yang digunakan untuk mengetahui seberapa besar pengaruh variabel bebas $\left(\mathrm{X}_{1}\right.$, $\mathrm{X}_{2}, \mathrm{X}_{3}$ ), yaitu harga, desain dan kualitas produk terhadap variabel terikat $(\mathrm{Y})$ yaitu kepuasan konsumen.

$$
F h=\frac{R^{2} / h}{\left(1-R^{2}\right) /(n-k-1)}
$$

Dimana :

$\mathrm{R}=$ Koefisien korelasi ganda

$\mathrm{k}=$ Jumlah variabel independen

$\mathrm{n}=$ Jumlah sampel

Metode hipotesis dalam penelitian ini adalah :

$$
\begin{aligned}
\mathrm{H}_{\mathrm{o}}: & \mathrm{b}_{1}=\mathrm{b}_{2}=\mathrm{b}_{3}=0 \quad \text { Artinya } \\
& \text { variabel bebas }\left(\mathrm{X}_{1} \mathrm{X}_{2} \mathrm{X}_{3}\right) \text { secara } \\
& \text { bersama-sama tidak } \\
& \text { berpengaruh signifikan terhadap } \\
& \text { variabel terikat. }
\end{aligned}
$$

$$
\mathrm{H}_{\mathrm{o}}: \mathrm{b}_{1} \# \mathrm{~b}_{2} \# \mathrm{~b}_{3} \# 0 \quad \text { Artinya }
$$$$
\text { variabel bebas }\left(\mathrm{X}_{1} \mathrm{X}_{2} \mathrm{X}_{3}\right) \text { secara }
$$
bersama-sama berpengaruh signifikan terhadap variabel terikat.

Kriteria pengambilan keputusannya adalah sebagai berikut :

Jika $\mathrm{F}_{\text {hitung }}>\mathrm{F}_{\text {tabel }}$, pada taraf kepercayaan $95 \%$ atau $=5 \%$, maka 
Penelitian Ilmu Manajemen \& Bisnis

Vol. 10 No. 1 Maret 2015

hipotesis dalam penelitian ini diterima.

Jika $\mathrm{F}_{\text {hitung }}<\mathrm{F}_{\text {tabel }}$ pada taraf kepercayaan $95 \%$ atau $=5 \%$, maka hipotesis dalam penelitian ini ditolak.

\section{Koefisien determinan $\left(\mathbf{R}^{2}\right)$}

Dari perhitungan $r$ (korelasi) dapat dilihat hubungan variabel bebas dan variabel terikat positif dan negatif. Determinan digunakan untuk melihat kontribusi variabel bebas yang diteliti $\left(\mathrm{X}_{1}, \mathrm{X}_{2} \mathrm{X}_{3}\right)$ yaitu harga, desain dan kualitas produk terhadap variabel terikat (Y) yaitu kepuasan konsumen secara bersama-sama dimana $0 \leq R^{2} \geq 1$. Hal in I berarti nilai $\mathrm{R}^{2}$ adalah 1 atau mendekati 1 , maka semakin kuat pengaruh variabel bebas terhadap variabel terikat. Sebaliknya apabila $\mathrm{R}^{2}$ mendekati 0 , maka semakin lemah pengaruh variabel bebas terhadap variabel terikat. Untuk mempermudah pengolahan data maka dipergunakan rumus rumus sebagai berikut:

$$
R^{2}=\frac{b(n \Sigma X Y)-(\Sigma X)(\Sigma Y)}{n\left(\Sigma Y^{2}\right)-(\Sigma Y)^{2}}
$$

\section{HASIL PENELITIAN DAN PEMBAHASAN \\ Hasil Penelitian

Metode Persamaan Regresi

Persamaan regresi berganda secara umum adalah :

$\mathbf{Y}=\mathbf{a}+\mathbf{b}_{1} \mathbf{X}_{1}+\mathbf{b}_{2} \mathbf{X}_{2}+\mathbf{b}_{3} \mathbf{X}_{3}$

Tabel 1. Koefisien Regresi

\begin{tabular}{|l|r|r|r|r|r|}
\hline \multirow{2}{*}{ Model } & \multicolumn{1}{|c|}{$\begin{array}{c}\text { Unstandardized } \\
\text { Coefficients }\end{array}$} & $\begin{array}{c}\text { Standardized } \\
\text { Coefficients }\end{array}$ & & \\
\cline { 2 - 5 } & \multicolumn{1}{|c|}{$\begin{array}{c}\text { Std. } \\
\text { Error }\end{array}$} & \multicolumn{1}{|c|}{ Beta } & \multirow{1}{*}{ t } & Sig. \\
\hline 1 (Constant) & 3.352 & 2.598 & & 1.290 & .203 \\
Harga & .359 & .066 & .437 & 5.424 & .000 \\
Desain & .184 & .069 & .199 & 2.674 & .010 \\
Kualitas & .519 & .081 & .520 & 6.426 & .000 \\
\hline \multicolumn{5}{|c|}{ Dari hasil pengolahan data, } \\
maka dapat dibuat persamaan
\end{tabular}

regresinya persamaan regresi tersebut adalah:

$$
\begin{aligned}
& Y=3,352+0,359 X_{1}+0,184 X_{2}+ \\
& \mathbf{0 , 5 1 9} \mathrm{X}_{3}
\end{aligned}
$$

- Konstanta sebesar 3,352 dapat diartikan bahwa Kepuasan Konsumen akan bernilai sebesar 3,352 pada saat harga, desain, dan kualitas bernilai nol (tidak ada.)

- Koefisien regresi $X_{1}$ sebesar 0,359 menyatakan bahwa kenaikan satu satuan Harga akan meningkatkan Kepuasan Konsumen sebesar 3,352.

- Koefisien regresi $X_{2}$ sebesar 0,184 menyatakan bahwa kenaikan satu satuan Desain akan meningkatkan Kepuasan Konsumen sebesar 3,352.

- Koefisien regresi $X_{3}$ sebesar 0,519 menyatakan bahwa kenaikan satu satuan Kualitas akan meningkatkan Kepuasan Konsumen sebesar 3,352.

\section{Koefisien Determinasi (R Square)}

Determianan digunakan untuk mengetahui seberapa besar variabel independen mampu menjelaskan pengaruh variabel dependen. Dari tabel 4.14 dapat diketahui besarnya angka $\mathrm{R}^{2}$ adalah 0,755 , yang berarti variabel Harga, Desain Produk dan Kualitas Produk, menjelaskan pengaruh terhadap variabel Kepuasan Konsumen sebesar $75,5 \%$ sedangkan sisanya 24,5 \% dipengaruhi oleh variabel-variabel lain di luar model penelitian ini.

\section{Pengujian Hipotesis}

Pengujian Hipotesis secara simultan menggunakan Uji-F

Uji hipotesis secara simultan diperlukan untuk mengetahui apakah model regresi sudah benar atau tidak. Uji hipotesis menggunakan nilai $\mathrm{F}$, 
Penelitian Ilmu Manajemen \& Bisnis

Vol. 10 No. 1 Maret 2015

yang diperoleh dari tabel Anova berikut ini :

Tabel 2.Hasil Uji-F

ANOVA $^{D}$

\begin{tabular}{|l|r|r|r|r|r|}
\hline Model & \multicolumn{1}{|c|}{$\begin{array}{c}\text { Sum of } \\
\text { Squares }\end{array}$} & df & $\begin{array}{c}\text { Mean } \\
\text { Square }\end{array}$ & F & Sig. \\
\hline 1 Regression & 280.186 & 3 & 93.395 & 47.318 & $.000^{a}$ \\
Residual & 90.794 & 46 & 1.974 & & \\
Total & 370.980 & 49 & & & \\
\hline
\end{tabular}

Pengujian hipotesis dilakukan dengan cara membandingkan besarnya angka $\mathrm{F}$ penelitian dengan $\mathrm{F}$ tabel, dengan kriteria sebagai berikut:

Jika $\mathrm{F}_{\text {hitung }}>\mathrm{F}_{\text {tabel}}$, maka Ho ditolak dan Ha diterima

Jika $\mathrm{F}_{\text {hitung }}<\mathrm{F}_{\text {tabel}}$, maka Ho diterima dan Ha ditolak

Berdasarkan tabel 2. angka $\mathrm{F}$ penelitian yang diperoleh dari hasil perhitungan adalah sebesar 47,318. Sedangkan angka $\mathrm{F}$ tabel dihitung dengan ketentuan yaitu taraf signifikansi $95 \%$ dan alpha 5\% serta derajat kebebasan (dk) dengan ketentuan $\mathrm{n}-2=50-2=48$. Dengan ketentuan tersebut diperoleh angka $\mathrm{F}_{\text {tabel }} \longrightarrow 2,79$.

Dengan demikian diperoleh nilai $\mathrm{F}_{\text {hitung }}=47,318>\mathrm{F}_{\text {tabel }}=2,79$. Karena $\mathrm{F}_{\text {hitung }}>\mathrm{F}_{\text {tabel }}$ yang berarti bahwa Ho ditolak dan Ha diterima, sehingga dapat disimpulkan bahwa terdapat pengaruh yang signifikan secara simultan antara Harga, Desain Produk dan Kualitas Produk terhadap Kepuasan Konsumen produk pestisida Antracol 70 WP pada PT.Bayer CropScience kepada Petani Desa Bah Jambi II Kecamatan Tanah Jawa Kabupaten Simalungun.

\section{Pengujian Hipotesis Secara Parsial menggunakan Uji t}

Untuk melihat besarnya pengaruh antara Harga, Desain Produk, Kualitas Produk terhadap Kepuasan Kosumen secara parsial, digunakan Uji t dengan menggunakan Tabel 1. Koefisien Regresi.

\section{Pengujian pengaruh Harga terhadap Kepuasan Konsumen}

Secara individual uji statistik yang digunakan adalah uji t. Hasil perhitungan SPSS diperoleh angka $t$ hitung sebesar 5,424. Untuk memperoleh besarnya $t$ tabel dilakukan perhitungan sebagai berikut:

Taraf signifikansi $95 \%$ dan alpha 5\%, serta derajat kebebasan (dk) dengan ketentuan $\mathrm{dk}=\mathrm{n}-2$ atau $50-2=48$. Dari ketentuan tersebut diperoleh angka $t$ tabel sebesar 2,001

Kriteria uji hipotesis adalah sebagai berikut:

Jika $t_{\text {hitung }}>t_{\text {tabel}}$, maka $\mathrm{Ho}_{1}$ ditolak dan $\mathrm{Ha}_{1}$ diterima

Jika $t_{\text {hitung }}<\mathrm{t}_{\text {tabel }}$, maka $\mathrm{Ho}_{1}$ diterima dan $\mathrm{Ha}_{1}$ ditolak

Berdasarkan

tabel

Coefficients, diperoleh nilai $t_{\text {hitung }}=$ $5.424>\mathrm{t}_{\text {tabel }}=2,001$, maka $\mathrm{Ho}_{1}$ ditolak dan $\mathrm{Ha}_{1}$ diterima. Artinya terdapat pengaruh yang signifikan dari Harga terhadap Kepuasan Konsumen.

\section{Pengujian Pengaruh Desain Produk terhadap Kepuasan Konsumen}

Hasil perhitungan SPSS diperoleh angka $t$ hitung sebesar 2,674 . untuk memperoleh besarnya $t$ tabel dilakukan perhitungan sebagai berikut:

Taraf signifkan 95\% dan alpha $5 \%$, serta derajat kebebasan (dk) dengan ketentuan $\mathrm{dk}=\mathrm{n}-2$ atau 50-2 $=$ 48. Dari ketentuan tersebut diperoleh angka $t$ tabel sebesar 2,001. Kriteria uji hipotesis adalah sebagai berikut:

Jika $t_{\text {hitung }}>t_{\text {tabel}}$, maka $\mathrm{Ho}_{1}$ ditolak dan $\mathrm{Ha}_{1}$ diterima 


\section{JURNAL PLANS}

Jika $\mathrm{t}_{\text {hitung }}<\mathrm{t}_{\text {tabel }}$, maka $\mathrm{Ho}_{1}$ diterima dan $\mathrm{Ha}_{1}$ ditolak

$$
\text { Berdasarkan }
$$

tabel

Coefficients, diperoleh nilai $t_{\text {hitung }}=$ $2,674>t_{\text {tabel }}=2,001$, maka $\mathrm{Ho}_{1}$ ditolak dan $\mathrm{Ha}_{1}$ diterima. Artinya terdapat pengaruh yang signifikan dari Desain Produk terhadap Kepuasan Konsumen.

\section{Pengujian Pengaruh Kualitas Produk terhadap Kepuasan Konsumen}

Hasil perhitungan SPSS diperoleh angka $t$ hitung sebesar 6,426 . untuk memperoleh besarnya $t$ tabel dilakukan perhitungan sebagai berikut:

Taraf signifkan 95\% dan alpha $5 \%$, serta derajat kebebasan (dk) dengan ketentuan $\mathrm{dk}=\mathrm{n}-2$ atau 50-2 $=$ 48. Dari ketentuan tersebut diperoleh angka t tabel sebesar 2,001. Kriteria uji hipotesis adalah sebagai berikut:

Jika $t_{\text {hitung }}>t_{\text {tabel}}$, maka $\mathrm{Ho}_{1}$ ditolak dan $\mathrm{Ha}_{1}$ diterima

Jika $\mathrm{t}_{\text {hitung }}<\mathrm{t}_{\text {tabel}}$, maka $\mathrm{Ho}_{1}$ diterima dan $\mathrm{Ha}_{1}$ ditolak

$$
\text { Berdasarkan }
$$

tabel

Coefficients, diperoleh nilai $t_{\text {hitung }}=$ $6,426>\mathrm{t}_{\text {tabel }}=2,001$, maka $\mathrm{Ho}_{1}$ ditolak dan $\mathrm{Ha}_{1}$ diterima. Artinya terdapat pengaruh yang signifikan dari Desain Produk terhadap Kepuasan Konsumen.

\section{Pembahasan Hasil Penelitian}

Berdasarkan hasil penelitian ini menyatakan pengaruh variabel Harga (X1), Desain Produk (X2) dan Kualitas Produk (X3) terhadap Kepuasan Konsumen (Y) ditunjukkan dari hasil analisis regresi linier berganda $\mathrm{Y}=3,352+0,359 \mathrm{X}_{1}+$ $0,184 \mathrm{X}_{2}+0,519 \mathrm{X}_{3}+$ e. Hal ini memberikan arti bahwa harga, desain produk, kualitas produk memiliki
Penelitian Ilmu Manajemen \& Bisnis

pengaruh signifikan kepuasan konsumen.

Hasil penelitian ini didukung oleh nilai koefisiean determinasi $\mathrm{R}^{2}$ sebesar 75,5\% terhadap kepuasan konsumen dan 24,5\% dipengaruhi oleh faktor lain di luar model regresi. Maka hasil penlitian yang menyatakan ada pengaruh harga terhadap kepuasan pelanggan, sesuai dengan teori menurut Kotler dan Keller (2009) yaitu harga sering ditetapkan untuk memuaskan permintaan atau mencerminkan premi yang bersedia dibayarkan konsumen untuk sebuah produk atau jasa dan hal ini juga sejalan dengan penelitian relevan yang telah dilakukan oleh Prestio (2012) menyimpulkan bahwa harga berpengaruh signifikan terhadap kepuasan pelanggan.

Demikian juga halnya dengan desain produk, teori yang dikemukakan oleh Tjiptono (2001) desain produk berpengaruh terhadap kepuasan konsumen yang telah terbukti dan hal ini juga sejalan dengan penelitian relevan yang telah dilakukan oleh Hidayani (2013) menyimpulkan bahwa desain berpengaruh signifikan terhadap kepuasan konsumen tas panggung merk Cozmeed pada Mahasiswa Fakultas Ekonomi Universitas Jember.

Dan juga dengan kualitas produk, teori yang dikemukakan Prawirosentono (2002:6) "kualitas produk adalah keadaan fisik, fungsi dan sifat suatu produk yang bersangkutan yang dapat memenuhi selera dan kebutuhan konsumen dengan memuaskan sesuai dengan nilai uang yang telah di keluarkan". Sehingga kualitas produk berpengaruh terhadap kepuasan konsumen yang telah terbukti dan hal ini juga sejalan dengan penelitian 


\section{JURNAL PLANS}

Penelitian Ilmu Manajemen \& Bisnis

Vol. 10 No. 1 Maret 2015

relevan yang telah dilakukan oleh Serlina (2010) menyimpulkan bahwa kualitas produk berpengaruh secara terhadap kepuasan pelanggan.

Untuk mengetahui variabel bebas mana yang paling mempengaruhi dominan terhadap variabel terikat, dapat dilihat dari nilai variabel harga, desain produk dan kualitas produk terhadap kepuasan konsumen. Berdasarkan hasil penelitian diperoleh bahwa harga $\left(\mathrm{X}_{1}\right)$ $5,424>t_{\text {tabel }}$ sebesar 2,001, variabel Desain Produk $\left(\mathrm{X}_{2}\right) 2,674>\mathrm{t}_{\text {tabel }}$ sebesar 2,001, sedangkan Kualitas Produk $\left(\mathrm{X}_{3}\right) 6,426>\mathrm{t}_{\text {tabel }}$ sebesar 2,001 . Berarti dalam hal ini variabel kualitas produk memberikan pengaruh yang paling signifikan terhadap kepuasan konsumen.

\section{PENUTUP}

\section{Kesimpulan}

Berdasarkan hasil analisis dan pembahasan yang telah dilakukan dalam penelitian ini, maka terdapat beberapa kesimpulan sebagai berikut:

1. Hasil penelitian ini menyatakan pengaruh variabel harga $\left(\mathrm{X}_{1}\right)$, desain produk $\left(\mathrm{X}_{2}\right)$ dan kualitas produk $\left(\mathrm{X}_{3}\right)$ terhadap kepuasan konsumen (Y) ditunjukan dari hasil analisis regresi berganda $\mathrm{Y}$ $=3,352+0,359 \mathrm{X}_{1}+0,184 \mathrm{X}_{2}+$ $0,519 \mathrm{X}_{3}+$ e. Hal ini memberikan arti bahwa variabel harga, desain produk dan kualitas produk memiliki pengaruh signifikan terhadap kepuasan konsumen.

2. Hasil penelitian ini didukung oleh nilai koefisien determinasi $\mathrm{R}^{2}$ sebesar $75,5 \%$ berarti dalam hal ini secara simultan harga, desain produk dan kualitas produk mempunyai pengaruh 75,5\% terhadap kepuasan konsumen dipengaruhi oleh faktor lain di luar model regresi.
3. Setelah dilakukan uji hipotesis secara Simultan (Uji F), variabel harga, desain produk dan kualitas produk secara bersama-sama berpengaruh signifikan terhadap kepuasan konsumen.

4. Setelah dilakukan uji hipotesis secara parsial (Uji t), variabel harga, desain produk dan kualitas produk berpengaruh signifikan terhadap kepuasan konsumen.

\section{DAFTAR PUSTAKA}

Arikunto, S. 2002. Prosedur Penelitian Suatu Pendekatan Praktek. Jakarta: Rineka Cipta.

Assauri, Sofjan. 2004. Manajemen Pemasaran Dasar Konsep Dan Strategi. Jakarta: Rajawali Press.

Dimyati. 2012. Model Struktural Pengaruh Atribut Produk terhadap Kepuasan dan Loyalitas Pelanggan Produk Pond's. Jurnal Aplikasi Manajemen. Vol.101, No.1. ISSN: 1693-5241.

Djaslim, S dan Yevis. 2002. Intisari Pemasaran dan Unsur-unsur Pemasaran. Bandung: CV.Linda Karya.

Ghozali, Imam. 2006. Statistik Nonparametrik. Semarang: Penerbit UNDIP.

Gitosudarmo. 2000. Manajemen Pemasaran. Edisi I. Yogjakarta.

Hidayani. 2013. Pengaruh Atribut Produk Terhadap Kepuasan Konsumen Tas Punggung Merk Cozmeed pada Mahasiswa Fakultas Ekonomi Universitas Jember. Skripsi. Jember. Fakultas Ekonomi Universitas Jember.

Irwan, Bambang. 2004. 10 Prinsip Kepuasan Pelanggan. Jakarta: 


\section{JURNAL PLANS}

PT Elex Media

Komputindo Gramedia.

Kotler, Philip. 2007. Manajemen Pemasaran. Jilid 1, Edisi Dua Belas. Jakarta: Indeks. . 2005. Manajemen Pemasaran. Terjemahan Teguh Hendra, Ruli., Molan Benjamin. Jakarta: PT Prenhallindo.

Lupiyoadi, Rambat. 2004. Manajemen Pemasaran : Pemasaran dan Praktek. Jakarta: Salemba Empat.

Malau, Serlina. 2010. Pengaruh Kualitas Produk dan Kualitas Pelayanan Terhadap Kepuasan Konsumen Pelanggan Pada Hypermart Sun Plaza Medan.

Skripsi. Medan. Fakultas Ekonomi Universitas Negeri Medan.

Prasetio. 2012. Pengaruh Kualitas Pelayanan dan Harga terhadap Kepuasan Pelanggan. Management Analysis Journal. Vol.1. No.2, 2012.Hal 1-7

Riduwan.2009. Metode dan Teknik Menyusun Tesis. Bandung: Alfabeta.

Setiadi, Nugroho. 2008. Perilaku Konsumen Konsep dan Implikasi untuk Strategi dan Penelitian Pemasaran. Jakarta: Kencana.
Penelitian Ilmu Manajemen \& Bisnis

Vol. 10 No. 1 Maret 2015

Simamora, B. 2007. Analisis Multivariate Pemasaran. Jakarta Gramedia Pustaka Utama.

Sudjana. 2002. Distribusi dan Strategi Pemasaran. Bandung: Tarsito

Sugiyono. 2008. Metodologi Penelitian Bisnis. Bandung : Alfabeta

Sumarwan. 2003. Perilaku Konsumen : Teori dan Penerapannya dalam Pemasaran. Cetakan Kedua. Jakarta: PT. Rineka Cipta.

dan T. Hani Handoko. 2000. Manajemen Pemsaran: Analisa Perilaku Konsumen. Edisi Pertama. Yogjakarta: Liberty

Tanuwijaya. 2013. Pengaruh Kualitas Layanan dan Kepuasan Produk terhadap Kepuasan Pelanggan Pipop Copy. Jurnal Neo-Bis. Vol.7, No.1, Juni 2013. Hal 1-15 ..

Tjiptono. Fandy. 2008. Service Management Mewujudkan Layanan Prima. Yogjakarta: Penerbit Andi.

Yustitia. 2009. Atribut Kepuasan Konsumen Produk Minuman Ringan Coca Cola di Kota Bandar Lampung. Jurnal Teknologi Industri dan Hasil Pertanian. Vol.14, No.1, Maret 2009. Hal 45-54. 